Pesq. Vet. Bras. 36(12):1171-1177, dezembro 2016 DOI: $10.1590 / \mathrm{S} 0100-736 \mathrm{X} 2016001200005$

\title{
A double-antibody sandwich ELISA based on the porcine circovirus type 2 (PCV2) propagated in cell culture for antibody detection ${ }^{1}$
}

\author{
Taís F. Cruz ${ }^{2,3}$, Tatiana M. Kanashiro ${ }^{2}$, Alessandra M.M.G. de Castro ${ }^{4}$, Cintia \\ M. Baldin ${ }^{4}$, Leonardo J. Richtzenhain ${ }^{4}$ and João P. Araujo Jr ${ }^{2,3 *}$
}

\begin{abstract}
Cruz T.F., Kanashiro T.M., Castro A.M.M.G., Baldin C.M., Richtzenhain L.J. \& Araujo Jr J.P. 2016. A double-antibody sandwich ELISA based on the porcine circovirus type 2 (PCV2) propagated in cell culture for antibody detection. Pesquisa Veterinária Brasileira 36(12):1171-1177. Departamento de Microbiologia e Imunologia, Instituto de Biociências, Universidade Estadual Paulista Júlio de Mesquita Filho, Botucatu, SP 18618970, Brazil. E-mail: jpessoa@ibb.unesp.br, tfcruz@yahoo.com.br

Few studies have described enzyme-linked immunosorbent assays (ELISAs) for the detection of antibodies against porcine circovirus type 2 (PCV2) based on antigens produced in cell culture. Furthermore, few articles have described viral purification techniques for members of the family Circoviridae. This occurs because circoviruses are difficult to isolate, noncytopathogenic, and produce low viral titres in cell culture. Thus, for overcoming these difficulties in the cultivation of PCV2, this study aimed to develop a double-antibody sandwich ELISA based on the cell culture antigen PCV2b for the quantification of anti-PCV2 antibodies. A $20 \%$ and 50\% discontinuous sucrose cushion was used for viral purification, which enabled the separation of cell culture proteins in the $20 \%$ sucrose cushion and a greater viral concentration in the $50 \%$ sucrose cushion. Following isopycnic centrifugation, PCV2 was concentrated in the band with density values from 1.330 to $1.395 \mathrm{~g} / \mathrm{cm}^{3}$. Viral purification was assessed using SDS-PAGE, indirect ELISA and electron microscopy. The standardised ELISA revealed a strong linear correlation $(r=0.826, p<0.001)$ when compared with a commercial ELISA kit. The assay exhibited low variability (inter-assay coefficient of variation of $4.24 \%$ and intra-assay of $1.80 \%$ ) and excellent analytical specificity conferred by the capture antibody produced in rabbit. Thus, this ELISA is a rapid, specific and convenient method for the detection of antibodies against PCV2 in studies of experimental and natural infection, and in monitoring the response to vaccination on commercial farms.
\end{abstract}

INDEX TERMS: Enzyme-linked immunosorbent assay, isopycnic centrifugation, porcine circovirus type 2 , sucrose cushion, antibody.

RESUMO.- [Sandwich ELISA com duplo anticorpo baseado no circovirus suíno tipo 2 (PCV2) produzido em cultivo celular para detecção de anticorpos.] Há poucos

\footnotetext{
${ }^{1}$ Received on December 22, 2015.

Accepted for publication on July 15, 2016.

${ }^{2}$ Departamento de Microbiologia e Imunologia, Instituto de Biociências, Universidade Estadual Paulista (Unesp), Botucatu, SP 18618-970, Brazil. *Corresponding autor: jpessoa@ibb.unesp.br, tfcruz@yahoo.com.br

${ }^{3}$ Instituto de Biotecnologia (Ibtec), Unesp, Botucatu, SP 18618-970, Brazil.

${ }^{4}$ Departamento de Medicina Veterinária Preventiva e Saúde Animal, Faculdade de Medicina Veterinária e Zootecnia, Universidade de São Paulo (USP), Av. Prof. Dr. Orlando Marques de Paiva 87, Cidade Universitária, São Paulo, SP 05508-270, Brazil.
}

relatos na literatura de métodos de ELISA (Enzyme-linked immunosorbent assay), para a detecção de anticorpos contra o circovírus suíno tipo 2 (PCV2), baseados em antígenos produzidos em cultivo celular, bem como uma escassez de trabalhos descrevendo técnicas de purificação viral para os membros da família Circoviridae. Isso ocorre, pois os circovírus são de difícil isolamento, não causam efeito citopático e produzem um baixo título viral em cultivo celular. Assim, para superar essas dificuldades encontradas no cultivo do PCV2, este estudo objetivou desenvolver um sandwich ELISA com duplo anticorpo, baseado no antígeno de PCV2 produzido em cultivo celular, para a quantificação de anticorpos anti-PCV2. Um colchão de sacarose descontínuo a $20 \%$ 
e $50 \%$ foi utilizado para a purificação viral, o qual possibilitou a separação das proteínas oriundas do cultivo celular no colchão de sacarose a $20 \%$ e uma maior concentração viral no colchão de sacarose a 50\%. Com a ultracentrifugação isopícnica, o PCV2 ficou mais concentrado na banda com valores de densidade de 1,330 a $1,395 \mathrm{~g} / \mathrm{cm}^{3}$. A purificação viral foi avaliada pelas técnicas de SDS-PAGE, ELISA indireto e microscopia eletrônica. Assim, o método de ELISA padronizado revelou uma forte correlação linear $(r=0,826$, $\mathrm{p}<0,001$ ) quando comparado com um kit de ELISA comercial. 0 ensaio demonstrou baixa variabilidade (coeficientes de variação inter-teste de 4,24\% e intra-teste de 1,80\%) e uma excelente especificidade analítica conferida pelo anticorpo de captura produzido em coelho. Portanto, o método de ELISA demonstrou ser rápido, específico e conveniente para a detecção de anticorpos contra o PCV2 em estudos de infecção natural e experimental, além da monitoria da resposta à vacinação contra o PCV2 em granjas comerciais.

TERMOS DE INDEXAÇÃO: Enzyme-linked immunosorbent assay, centrifugação isopícnica, circovirus suíno tipo 2 , colchão de sacarose, anticorpo.

\section{INTRODUCTION}

Porcine circoviruses (PCVs) belong to the family Circoviridae, genus Circovirus. PCVs are small (17-nm-diameter), icosahedral, non-enveloped viruses containing a circular single-strand DNA genome. There are two types of PCV: the nonpathogenic PCV1, persistently contaminating the pig kidney cell cultures PK-15 (ATCC CCL 33) (Tischer et al. 1974), and PCV2, which is the primary agent of various syndromes in pigs termed porcine circovirus diseases (PCVD) (Segalés 2012). Post-weaning multisystemic wasting syndrome (PMWS) or PCV2-systemic disease (PCV2-SD) is the main clinical manifestation of PCVD and is of great economic importance worldwide (Segalés 2012).

Four open reading frames (ORFs) are encoded by the PCV2 genome. ORF1 encodes the Rep and Rep' proteins involved in viral replication (Cheung 2003). ORF3 (Liu et al. 2005,2006 ) and ORF4 (He et al. 2013) encodes non-structural (NS) proteins related to viral pathogenesis. ORF2 encodes the major structural capsid protein (Cap, $30 \mathrm{kDa}$ ), which is also the main antigenic determinant of the virus (Nawagitgul et al. 2000).

The detection of antibodies against the virus has no diagnostic value for PCVD because PCV2 is widespread worldwide (Allan \& Ellis 2000). However, the quantification of antibodies is very useful for studies on PCV2 infection dynamics and its relationship with PMWS, in the association with protection against PCV2 infection, in serological surveys, in the assessing the effectiveness of vaccines in development, in the adoption of vaccination programs analysing the level and decline of passive immunity, in the evaluation of the animal response to vaccination and as an indicator of viral exposure and circulation on farms (Nawagitgul et al. 2002, Blanchard et al. 2003, Gerber et al. 2009).

In this context, indirect immunofluorescence (IIF) (Allan et al. 1999) and immunoperoxidase monolayer assay (IPMA) (Rodríguez-Arrioja et al. 2000) methods are ty- pically used in detecting antibodies against PCV2. However, these methods are extremely laborious, are time consuming and require experienced professionals for the preparation of infected cells and for the interpretation of results (Nawagitgul et al. 2002).

Conversely, enzyme-linked immunosorbent assays (ELISAs) are methods with high analytical sensitivity and specificity, low cost, fast, and may be automated, favouring the large-scale study of several serum samples. For the detection of antibodies against PCV2, the systems of antigen production in Escherichia coli (Shang et al. 2008, Marcekova et al. 2009, Sun et al. 2010, Ge et al. 2012), insect cells (Nawagitgul et al. 2002, Blanchard et al. 2003, Liu et al. 2004) and insect larvae (Pérez-Martín et al. 2008) exhibit more restricted access to techniques when compared with traditional antigen production in cell culture. However, these systems exhibit high purified protein yields (Nawagitgul et al. 2002, Spencer et al. 2007), which could be used in indirect ELISA methods. Production of pure or partly purified viral antigens with good yield commonly used in these ELISA methods is highly dependent on the amount of antigen mass that is produced.

Few published studies (Walker et al. 2000, Nawagitgul et al. 2002, Huang et al. 2011) have used the ELISA method to detect antibodies against PCV2 based on antigens produced in cell culture because PCVs are difficult to isolate in cell culture, do not cause cytopathic effects and produce low viral titres (Meerts et al. 2005, Chen et al. 2013).

This problem may be circumvented when the antigen is bound to a microplate well via a specific antibody (Crowther 1995a). The specific capture antibody will bind to the antigen in a proportional manner to a wide range of protein concentrations, which enables the use of the crude or semi-purified virus produced in cell culture as the antigen. Therefore, these assays provide reproducible results, and the use of crude antigen makes this technique more accessible and fast. Besides, the preparation of cell cultures of swine testicle (ST) persistently infected with PCV2b with high viral loads was previously reported (Cruz \& Araujo Jr 2014), enabling its use as source of PCV2 antigen for serological techniques.

Thus, this study aimed to develop a double-antibody sandwich ELISA for the detection of antibodies against PCV2 produced in cell culture. This study also aimed to describe the method of PCV2 purification that is of critical importance in the production of specific antibodies.

\section{MATERIALS AND METHODS}

Viral antigens. The supernatant and lysate of PCV1-free ST cells and infected with PCV2b (GenBank accession KF374705) derived from the virus culture were used as the viral stock as previously described (Cruz \& Araujo Jr 2014). This viral stock was frozen and thawed three times, treated with 5\% Vertrel ${ }^{\circledR}$ (DuPont, Wilmington, USA) and clarified at $10,000 \mathrm{xg}$ for $10 \mathrm{~min}$ at $4^{\circ} \mathrm{C}$. The supernatant was used in the viral purification and as the PCV2 antigen (PCV2 Ag) in the double-antibody sandwich ELISA. Lysates of uninfected ST cells were prepared in the same way and used as ST antigen (ST Ag). PK-15 cell lysate persistently infected with PCV1 treated with D-glucosamine (Tischer et al. 1987) was used as PCV1 antigen (PCV1 Ag). 
PCV2 Purification. The pellet from the clarification was treated with lysis buffer (0.05 M Tris, $0.15 \mathrm{M} \mathrm{NaCl}, 0.002 \mathrm{M}$ EDTA, $0.1 \%$ SDS, $1 \%$ Triton $\mathrm{X}-100,0.1 \%$ sodium azide, $\mathrm{pH} 8.0$ ) as previously described (Pogranichnyy et al. 2000). The supernatants (from the resuspended pellet and from the cell culture supernatant) were pooled and ultracentrifuged at $190,000 \times \mathrm{xg}$ for $3 \mathrm{~h}$ at $4^{\circ} \mathrm{C}$ for the concentration of the virus. The pellet was resuspended, loaded on a $20 \%$ and $50 \%(\mathrm{w} / \mathrm{w})$ discontinuous sucrose cushion, and ultracentrifuged at 190,000xg for $3 \mathrm{~h}$ at $4^{\circ} \mathrm{C}$. Following ultracentrifugation, $0.2 \mathrm{~mL}$ fractions were collected. Refractometry index (RI, Brix Scale) and optical density (OD) at 260 and 280nm were measured for each fraction. Fractions pelleted in the $50 \%$ sucrose cushion were dialysed against PBS $\left(0.01 \mathrm{M} \mathrm{PO}_{4}^{-2}, 0.14 \mathrm{M} \mathrm{NaCl}, \mathrm{pH}\right.$ 7.4). This procedure was performed twice (1st and 2nd sucrose cushion). Subsequently, virus was banded in an isopycnic caesium chloride gradient $(37 \% \mathrm{CsCl}, \mathrm{w} / \mathrm{w})$ by ultracentrifugation at $238,000 x g$ for $72 \mathrm{~h}$ at $4^{\circ} \mathrm{C}$. The RI (Brix Scale) and ODs (260 and $280 \mathrm{~nm})$ were measured for each collected fraction $(0.4 \mathrm{~mL})$. The RI values were converted into values of the density fluctuation in $\mathrm{CsCl}$. Fractions with high ODs and density fluctuation values in $\mathrm{CsCl}$ approaching the porcine circovirus $\left(1.37 \mathrm{~g} / \mathrm{cm}^{3}\right)$ were selected and dialysed against PBS pH 7.4. Aliquots from each phase of the viral purification procedure were separated, and the protein concentrations were assessed using the bicinchoninic acid (BCA) method and bovine serum albumin (BSA) as a protein standard (Smith et al. 1985).

Analysis of the PCV2 purification. All aliquots $(n=10)$ separated from the viral purification were analysed at the concentration of $0.2 \mu \mathrm{g} / \mu \mathrm{L}$ by SDS-PAGE (sodium dodecyl sulphate-polyacrylamide gel electrophoresis). Resolving gels (12.5\%) were prepared as previously described (Laemmli 1970). The same aliquots $(\mathrm{n}=10)$ were analysed by indirect ELISA, as previously described (Liu et al. 2004) with some modifications. For this purpose, a 96-well microplate (Medisorp, Nunc, Waltham, USA) was coated with each one of the aliquots/well at a concentration of $10 \mathrm{ng} / \mu \mathrm{L}$ with PBS, pH 7.4. Rabbit anti-PCV2 serum diluted at 1:5000 (Sorden et al. 1999) was used as the detector antibody. The horseradish peroxidase (HRP)-conjugated bovine anti-rabbit immunoglobulins (Santa Cruz Biotechnology, Dallas, USA) was used at a 1:5000 dilution. The fractions selected from the isopycnic $\mathrm{CsCl}$ gradient after dialysis were analysed using a CM100 transmission electron microscope (TEM, Philips, Eindhoven, Netherlands), and 200-mesh grids with Formvar film were mounted with the samples and negatively stained with $2 \%(\mathrm{w} / \mathrm{v})$ phosphotungstic acid (PTA), pH 7.4. All analyses were performed to select the fraction with higher purity and yield.

Capture antibody production. A female rabbit (Protocol \#103/2010-CEUA, Ethics Committee on Animal Use of FMVZ, Unesp) was immunised with purified virus (fraction 6, band 2) at $50 \mu \mathrm{g} / \mathrm{mL}(\mathrm{v} / \mathrm{v})$ following the immunisation method previously described (Johnstone \& Thorpe 1996). The purification of antiPCV2 rabbit IgG using HiTrap ${ }^{\circledR}$ Protein G 5mL column (GE Healthcare, Buckinghamshire, United Kingdom) was performed according to the manufacturer's instructions. The protein concentration of purified IgG was $8 \mathrm{mg} / \mathrm{mL}$ determined by the BCA method, and BSA was used as a protein standard (Smith et al. 1985).

Positive and negative reference sera. A pool of 5 samples collected from animals negative by IPMA was used as negative reference serum. The positive reference serum consisted of a pool of 22 samples collected from pigs positive by IPMA. IPMA was performed as previously described (Rodríguez-Arrioja et al. 2000).

Assessment of the optimal concentrations of capture antibody, PCV2 Ag, and test sera. Checkerboard titrations were performed to define the optimal concentrations of the ELISA immunoreagents. The purified rabbit anti-PCV2 IgG was tested as capture antibody at concentrations of $20 \mu \mathrm{g} / \mathrm{mL}, 10 \mu \mathrm{g} / \mathrm{mL}, 5 \mu \mathrm{g} /$ $\mathrm{mL}, 2 \mu \mathrm{g} / \mathrm{mL}$, and $1 \mu \mathrm{g} / \mathrm{mL}$. Porcine sera with high, medium, and low titer according to the IPMA (Rodríguez-Arrioja et al. 2000) were evaluated at 1:100 and 1:200 dilutions. The PCV2 Ag was tested at dilutions of $1: 2 ; 1: 4$, and 1:6. PBST (PBS pH 7.4 with $0.05 \%(\mathrm{v} / \mathrm{v}$ ) Tween 20 ) was used as negative antigen control. The smallest concentration able to produce a high OD and with minimal noise was chosen as the concentration of use for each immunoreagent.

Specificity of the capture antibody. The capture antibody was tested against the antigens PCV2 Ag, ST Ag, and PCV1 Ag. Negative and positive reference sera were used in this reaction as test sera. The used concentrations of the capture antibody, antigens and sera were previously established.

Development of double-antibody sandwich ELISA. The test sera and the positive and negative reference sera were diluted to 1:200 using a diluent solution (PBST and 10\% (w/v) skimmed milk powder) with $10 \%(\mathrm{v} / \mathrm{v})$ normal rabbit serum (Gibco, Grand Island, USA) in a previously blocked U-bottom microplate, named microplate dilution. The diluted sera were incubated, in a humid chamber, for $18 \mathrm{~h}$ at $4^{\circ} \mathrm{C}$ and subsequently at $37^{\circ} \mathrm{C}$ for $1 \mathrm{~h}$ and $45 \mathrm{~min}$. A 96-well microplate (Maxisorp, Nunc, Waltham, USA) named reaction microplate, was coated with capture antibody (purified rabbit anti-PCV2 IgG, $0.005 \mathrm{mg} / \mathrm{mL}$ ) with $0.05 \mathrm{M}$ carbonate/bicarbonate buffer, $\mathrm{pH} 9.6$ and incubated for $18 \mathrm{~h}$ at $4^{\circ} \mathrm{C}$ in a humid chamber. After the adsorption step, the reaction microplate was blocked using the blocking solution (0.05 M carbonate/bicarbonate buffer pH 9.6 with $10 \%$ (w/v) skimmed milk powder) for $45 \mathrm{~min}$ at $37^{\circ} \mathrm{C}$ in humid chamber. Subsequently, the PCV2 Ag was prepared 1:2 with diluent solution and added to the even lanes. The negative antigen control (PBST) was added to the odd lanes. The reaction microplate was incubated for $1 \mathrm{~h}$ at $37^{\circ} \mathrm{C}$ in a humid chamber. The previously diluted test and reference sera (microplate dilution) were transferred into the reaction microplate, in duplicate for PCV2 Ag e antigen control (PBST), and the incubation was performed for $1 \mathrm{~h}$ at $37^{\circ} \mathrm{C}$ in a humid chamber. After, the HRP-conjugated rabbit anti-porcine IgG (Sigma, Saint Louis, USA) was diluted 1:5000 using the diluent solution and added to the wells. The reaction microplate was incubated for $1 \mathrm{~h}$ at $37^{\circ} \mathrm{C}$ in a humid chamber. The enzyme substrate solution $(2.5 \mu \mathrm{l}$ of $30 \%$ hydrogen peroxide) with the chromogen $\left(100 \mu \mathrm{L}\right.$ of $10 \mathrm{mg} / \mathrm{mL} 3,3^{\prime}, 5,5^{\prime}$ tetramethylbenzidine) prepared with $10 \mathrm{~mL}$ of $0.1 \mathrm{~mol} / \mathrm{L}$ citrate/ acetate buffer, pH 6.0 was added to each well. The reaction microplate was maintained under constant stirring for $15 \mathrm{~min}$ at room temperature. The colorimetric reaction was blocked with a solution of $2 \mathrm{~mol} / \mathrm{L} \mathrm{HCl}(50 \mu \mathrm{L} /$ well $)$, and the OD was read at 450nm (Multiskan EX, Labsystems, Vienna, USA). Reaction microplate washing was conducted five times $(300 \mu \mathrm{L} /$ well) with PBST, pH 7.4 between each step of the reaction, except after the substrate/chromogen step. A volume of $100 \mu \mathrm{L} /$ well was used for the capture antibody, antigen, test sera, immunoenzymatic conjugate, and substrate/chromogen.

Duplicates of test sera were considered satisfactory when the standard deviation (SD) of the ODs was less than 0.2. The corrected OD (COD) of each sample was calculated by subtracting the mean OD of the control antigen (PBST) from the mean OD obtained for the PCV2 Ag. The ELISA index (EI) was calculated for each test sera using the following formula: $\mathrm{EI}=\left(\mathrm{COD}_{\text {test serum }}-\mathrm{COD}_{\text {negative }}\right) /$ $\left(\mathrm{COD}_{\text {positive }}-\mathrm{COD}_{\text {negative }}\right)$, where $\mathrm{COD}$ test serum $=$ mean COD of the test serum; $\mathrm{COD}_{\text {negative }}=$ mean COD of the negative reference serum; and $\mathrm{COD}_{\text {positive }}=$ mean $\mathrm{COD}$ of the positive reference serum.

Comparison of the double-antibody sandwich ELISA with the reference test. Serum samples from fifteen crossbred piglets born to sows vaccinated against PCV2 (Circovac ${ }^{\circledR}$, Merial, Lyon, 
France) were used in this study. The animals were housed under controlled conditions to obtention of piglets negative for PCV2 as previously described (Castro et al. 2013). Serum samples ( $n=105)$ were collected from animals at 7, 14, 21, 28, 35, 42, and 49 days of age. Subsequently, 3 piglets ( $\mathrm{n}=15$ sera) were monitored to check for late seroconversion at 56, 63, 70, 77, and 84 days of age. Therefore, a total of 120 piglet serum samples were analysed by double-antibody sandwich ELISA and reference test. Serum samples and nasal and faecal swabs collected from pigs were tested by PCR, as previously described (Castro et al. 2013), to prove that the piglets were negative for PCV2.

The ELISA kit Ingezim Circovirus IgG/IgM (Ingenasa, Madrid, Spain) was used as a reference test for comparison with the double-antibody sandwich ELISA. The detection of IgG antibodies specific for PCV2 using the reference test was performed according to the manufacturer's instructions.

Assessment of the correlation between ELISA tests. The ELISA developed in this study was correlated with the reference test using the Spearman nonparametric method, with $\mathrm{p}<0.05$ representing statistical significance.

Evaluation of the repeatability of the double-antibody sandwich ELISA. The same test serum with the medium titer ac-

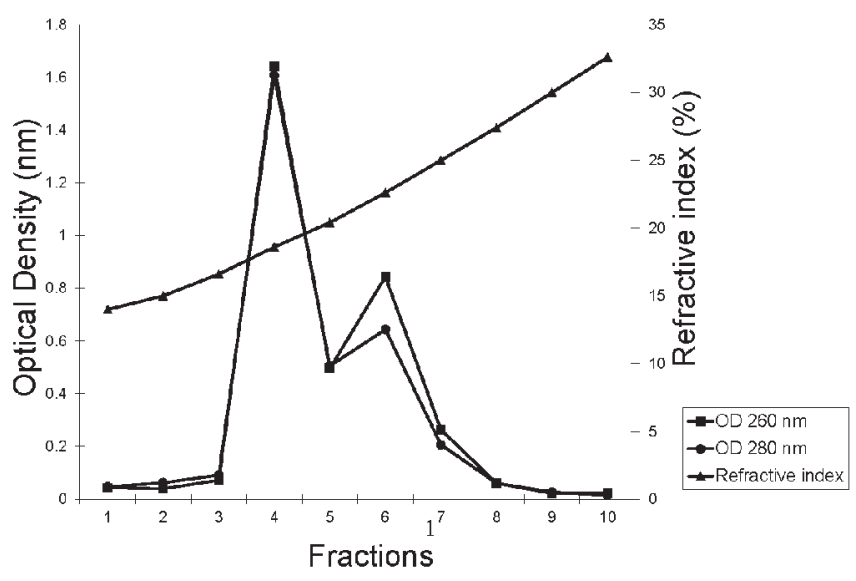

Fig.1. PCV2 purification. Optical densities (260 and 280nm) and refractometry index (RI, Brix scale) of fractions collected from the top of the tube (fraction 1) to the bottom (fraction 10) of the isopycnic $\mathrm{CsCl}$ gradient $(37 \% \mathrm{CsCl})$. cording to the IPMA (Rodríguez-Arrioja et al. 2000) was used for the inter-test and intra-test analyses. This serum was tested in 11 reactions conducted during the application of the method in the inter-test. The same serum was tested in 11 different wells of the microplate for the intra-test analysis. The means, SD, and coefficients of variation were calculated for both analyses.

\section{RESULTS}

\section{PCV2 purification}

Two bands (bands 1 and 2) were observed in the tube following $\mathrm{CsCl}$ isopycnic centrifugation. The RI of fractions 4 and 5 (band 1) corresponded to a density ranging from 1.269 to $1.300 \mathrm{~g} / \mathrm{cm}^{3} \mathrm{CsCl}$. The RI of fractions 6 and 7 (band 2) corresponded to a density ranging from 1.330 to $1.395 \mathrm{~g} /$ $\mathrm{cm}^{3}$. These results are presented in Figure 1. The protein concentrations of each fraction were $1.643 \mu \mathrm{g} / \mathrm{mL}$ (fraction 4, band 1), $0.747 \mu \mathrm{g} / \mathrm{mL}$ (fraction 5, band 1), $0.329 \mu \mathrm{g} / \mathrm{mL}$ (fraction 6, band 2), and $0.284 \mu \mathrm{g} / \mathrm{mL}$ (fraction 7, band 2) relative to the BSA standard.

\section{Analysis of PCV2 purification aliquots}

It was observed a strong band of approximately 66.2 $\mathrm{kDa}$, most likely to be BSA, in the aliquots of the initial stages of viral purification by SDS-PAGE (Fig.2A). Indirect ELISA revealed $\mathrm{OD}_{450}$ values smaller than 0.05 in the same samples, except for the concentrated virus, which had an $\mathrm{OD}_{450}$ value of 0.206. After the sucrose cushion, the 66.2$\mathrm{kDa}$ band in lanes 5 and 6 (Fig.2B) was weaker, and a sharp band of approximately $31 \mathrm{kDa}$, most likely to be the viral capsid protein, was observed with higher intensity by SDS-PAGE. The fractions collected from band 1 (Fig.2B, lanes 7-8) after the formation of the isopycnic $\mathrm{CsCl}$ gradient produced SDS-PAGE results similar to the fractions from the sucrose cushion. Only the band of approximately 31 $\mathrm{kDa}$ was observed by SDS-PAGE in the fractions of band 2 (Fig.2B, lanes 9-10). All of these samples exhibited $\mathrm{OD}_{450}$ readings greater than 1.4 in the indirect ELISA. Isometric structures with sizes similar to that of PCV were observed in greater quantity in fraction 6 (band 2) than in fraction 4 (band 1) under TEM (Fig.2C). Therefore, fraction 6 (band 2 ) was selected to produce the capture antibody.
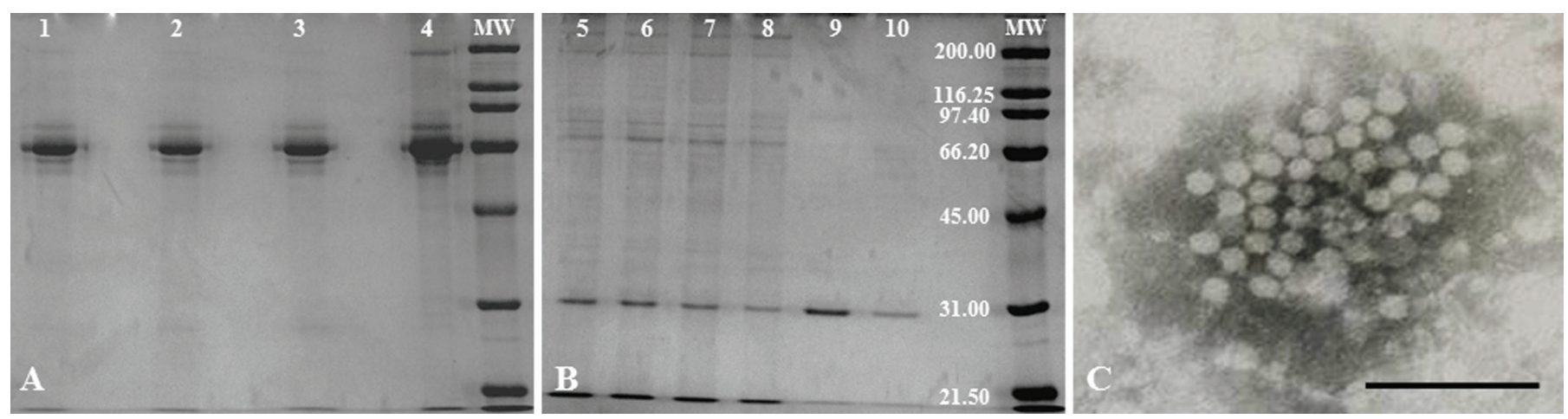

Fig.2. Analysis of PCV2 purification aliquots. (A) SDS-PAGE, lane 1: ST cell lysate infected with PCV2, lane 2: supernatants after clarification, lane 3: supernatant after ultracentrifugation for virus concentration, lane 4: concentrated virus pellet. (B) SDS-PAGE, lane 5: fractions pooled in the $1^{\text {st }}$ sucrose cushion, lane 6: fractions pooled in the $2^{\text {nd }}$ sucrose cushion, lane 7: Fraction 4 (band 1), lane 8: Fraction 5 (band 1), lane 9: Fraction 6 (band 2), lane 10: Fraction 7 (band 2), lane MW: molecular mass marker (6.5 to $200 \mathrm{kDa}$ ). (C) Transmission electron microscopy of fraction 6 (band 2) from the purification of PCV2. Staining with $2 \%$ phosphotungstic acid. Magnification of 231,000x. Bar $=100 \mathrm{~nm}$. 


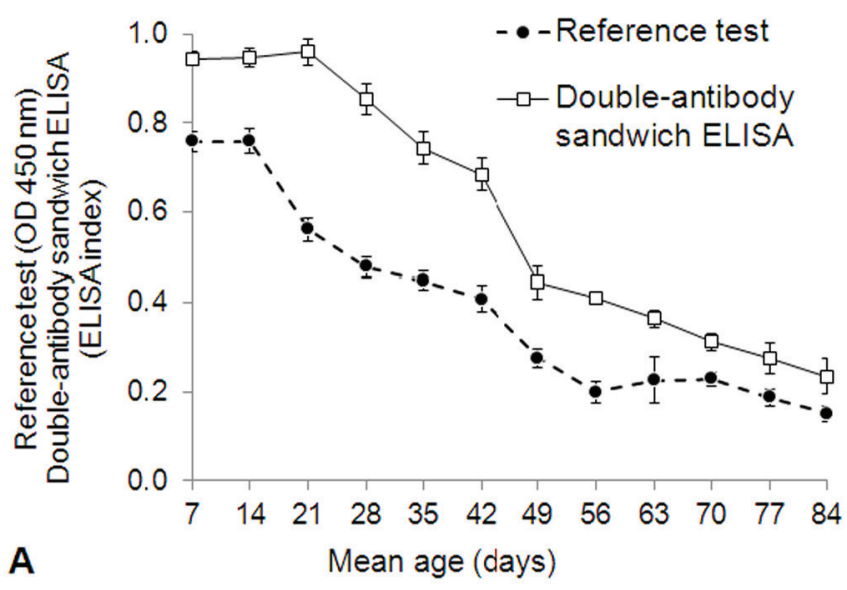

A

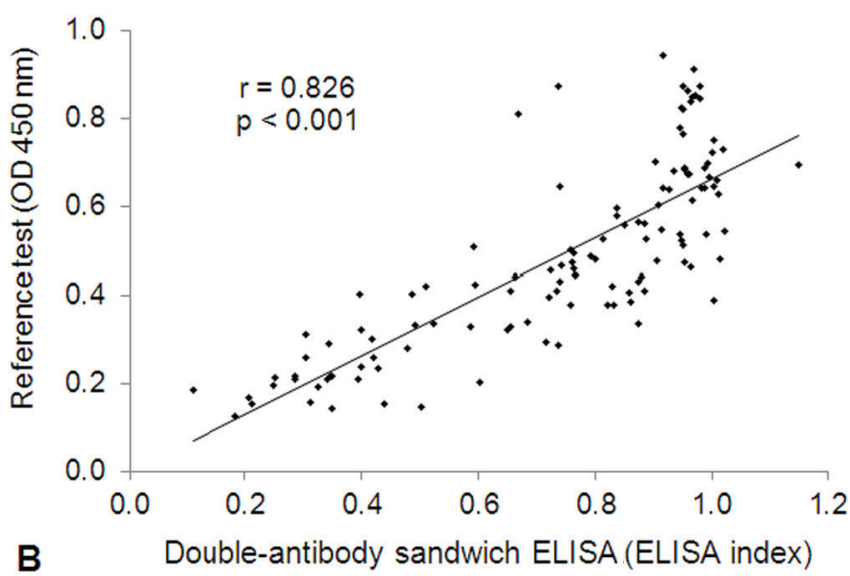

Fig.3. Correlation between the reference test (commercial ELISA kit) and double-antibody sandwich ELISA. Serum samples $(n=120)$ collected from piglets housed under controlled conditions to obtaining PCV2-negative animals. (A) Response kinetics of anti-PCV2 antibodies according to both ELISA tests. Reference test: mean OD $(450 \mathrm{~nm}) \pm$ standard error (SE). Double-antibody sandwich ELISA: mean ELISA index \pm SE. (B) Scatterplot. Spearman correlation between both ELISA tests $(\mathrm{r}=0.826, \mathrm{p}<0.001)$.

\section{Specificity of the capture antibody}

The capture antibody reacted only with PCV2 Ag when compared with the positive reference sera (mean $\mathrm{OD}_{450}$ value of 2.1). The $\mathrm{OD}_{450}$ values obtained to the other antigens were lower than 0.004 .

\section{Repeatability of double-antibody sandwich ELISA}

The coefficient of variation (mean \pm SD) of the inter-test with 11 replicates was $4.24 \%(0.826 \pm 0.035)$. The corresponding value for the intra-test analysis was $1.80 \%(0.868$ \pm 0.0156 ).

\section{Correlation between the reference test and double-an- tibody sandwich ELISA}

There was no seroconversion in the piglets until the age of 84 days. It was observed a gradual decrease in antibodies according to both ELISA tests (Fig.3A). The Spearman coefficient correlation assessed for both tests $(r=0.826$; $\mathrm{p}<0.001$ ) indicated a strong linear correlation between the methods (Fig.3B).

\section{DISCUSSION}

In the ELISA system proposed in this study, the antigen was captured using a specific antibody coating the microplate. The analytic specificity of this system depended strongly on the capture antibody, which was produced by rabbit immunisation with the purified virus. The viral stock used in the virus purification was prepared from the PCV2 cultivated in ST cells. To eliminate smaller proteins derived from the cell culture, the standardisation of the viral purification procedure for PCV2 with the evaluation of each step was essential to perform this study.

Bovine serum albumin derived from the cell culture was still present in the pellet of concentrated virus after the viral concentration step by ultracentrifugation. A $20 \%$ and $50 \%$ discontinuous sucrose cushion was prepared to separate proteins smaller than the virus. These proteins were more concentrated in the $20 \%$ sucrose cushion because BSA has a smaller coefficient of sedimentation (7 S) and molecular mass (66 kDa). However, the PCV2 virus particles, which have a coefficient of sedimentation of $57 \mathrm{~S}$ (Allan et al. 1994) and a molecular mass of approximately $1680 \mathrm{kDa}$ (Crowther et al. 2003), reached the $50 \%$ sucrose cushion at a faster speed than BSA, concentrating in this cushion. Therefore, a strong band of $66 \mathrm{kDa}$ (BSA) was observed in all samples of the initial stages of viral purification by SDS-PAGE. The 66-kDa band became weaker, and a greater viral concentration occurred after the sucrose cushion. A sharp band with less than $31 \mathrm{kDa}$ was observed and confirmed by indirect ELISA for antigen detection as the capsid protein (ORF2) of PCV2, which has a molecular mass of $30 \mathrm{kDa}$ (Nawagitgul et al. 2000). Furthermore, a tube containing only foetal bovine serum was also ultracentrifuged to work as a control in the $20 \%$ and $50 \%$ discontinuous sucrose cushion stage (data not shown). Optical density at $260 \mathrm{~nm}$ values $>2.6$ and $\mathrm{OD}_{280}$ values $>4.07$ were observed in the $20 \%$ sucrose cushion fractions. The OD values of the $50 \%$ sucrose cushion fractions decreased: $\mathrm{OD}_{260}<0.26$ and $\mathrm{OD}_{280}<0.30$. The fractions from the $20 \%$ sucrose cushion of the foetal bovine serum tube also exhibited similar OD values at 260 and $280 \mathrm{~nm}$ when compared with the tubes containing PCV2. However, the OD values at 260 and $280 \mathrm{~nm}$ of the fractions from the $50 \%$ sucrose cushion containing PCV2 were greater $\left(\mathrm{OD}_{260}>2.21 ; \mathrm{OD}_{280}\right.$ $>1.60$ ) than the foetal bovine serum tube. Thus, the separation of BSA in the fractions from the $20 \%$ sucrose cushion could be confirmed.

The formation of two bands in the tube occurred after the isopycnic $\mathrm{CsCl}$ gradient reached equilibrium, most likely due to the presence of BSA in addition to PCV2 forming band 1, whereas band 2 was only formed by PCV2, according to the SDS-PAGE results. Furthermore, the fractions of band 2 exhibited density values ranging from 1.330 to $1.395 \mathrm{~g} / \mathrm{cm}^{3}$, whereas the fractions of band 1 exhibited density values ranging from 1.269 to $1.300 \mathrm{~g} / \mathrm{cm}^{3}$. The presence of virus in band 1 may also result from empty viral particles (without DNA), which exhibit slightly smaller fluctuation densities. These results may also indicate that the virus was more concentrated in the fractions of band 2, which is the band of true equilibrium of the virus in the isopycnic 
CsCl gradient, because the PCV exhibits a fluctuation density in $\mathrm{CsCl}$ of approximately $1.37 \mathrm{~g} / \mathrm{cm}^{3}$ (Tischer et al. 1995).

The indirect ELISA method for antigen detection using polyclonal rabbit serum against PCV2 confirmed the results found by SDS-PAGE. Optical density values at $450 \mathrm{~nm}$ were produced at low levels at the beginning of viral purification because those samples were not fully purified, given the presence of other proteins derived from cell culture in greater amounts. Thus, with the occurrence of viral purification process, OD values at $450 \mathrm{~nm}$ greater than 1.4 were found by indirect ELISA. Finally, isometric particles morphologically similar to PCV were observed in fraction 6 (band 2) in greater quantity than in fraction 4 (band 1) under TEM, confirming the purification of PCV2.

The immunisation of the rabbit for capture antibody production was performed using fraction 6 (band 2) after preparing the purified virus. The specificity of the capture antibody was confirmed by the $\mathrm{OD}_{450}$ value $(>2.1)$ observed for the PCV2 Ag. The values for the other antigens (ST $\mathrm{Ag}$ and PCV1 Ag) were smaller than 0.004. Thus, these results also confirm the specificity of the capture antibody produced.

The results from the evaluation of the repeatability of double-antibody sandwich ELISA revealed that the test was reproducible. This great repeatability may result from the optimisation of the method and the stability of the viral antigen prepared from cell culture because the viral particles of PCV2, which is a non-enveloped virus, are quite resistant to the conditions of the environment. In comparison with recombinant antigens, an indirect ELISA was developed for the detection of antibodies against PCV2 using an antigenic domain of ORF2 expressed in Escherichia coli (Sun et al. 2010). The authors reported lower stability for the recombinant proteins produced, which affected the inter-test repeatability, producing a higher coefficient of variation. Furthermore, intact viral particles exhibit a perfect structure, whereas recombinant proteins are not always fully refolded, hampering antibody recognition against these proteins (Huang et al. 2011). Furthermore, the number of epitopes available to react with the antibodies in the test sera may be much higher than those found in recombinant proteins (Crowther 1995b). The total antibodies quantified using ELISA systems based on intact virus may likely be more correlated with protection against viral infection when compared with the total antibodies detected by immunoenzymatic assays produced with recombinant proteins because of these structural characteristics. The bonds formed in the antigen-antibody complex may exhibit greater affinity and stability than bonds that occur against a short peptide in the case of intact virus used in the ELISA system (Sun et al. 2010). Thus, the stability and structural conformation characteristics of the antigen produced in cell culture favoured the great repeatability of the ELISA method developed in this study.

The low viral yield is a disadvantage of working with cell culture antigens compared with the use of recombinant proteins, especially for the preparation of a high-quality antigen (Nawagitgul et al. 2002, Spencer et al. 2007). The use of purified virus only for the production of capture antibody reduced the amount of reagent required for the development of the method. The capture antibody was highly specific for PCV2, which reinforces the optimal characteristic of PCV2 antigen stability. Moreover, the difficulty of isolating and maintaining PCV2 in growth remains a problem faced by many laboratories. However, the preparation of ST cells persistently infected with PCV2b (Cruz \& Araujo Jr 2014) enabled the development of the ELISA method presented in this study. Here, the ST cell cultures persistently infected with PCV2b were adapted to cell culture medium without serum, continuously providing cell supernatant with approximately $10^{8}$ DNA copies of PCV $/ \mathrm{mL}$ by quantitative PCR (data not shown). This supernatant was used in double-antibody sandwich ELISA as the viral antigen. Several serum samples ( $n=481$ ) from piglets and sows from Brazilian commercial farms vaccinated against PCV2 were tested using the ELISA method. Satisfactory repeatability results (coefficient of variation, mean $\pm \mathrm{SD}$ ) for the inter-test (3.95\%; $0.859 \pm$ 0.034 ) and intra-test $(1.79 \%$; $0.903 \pm 0.016)$ analyses were also found with this antigen (data not shown).

A cut-off point was not defined for the ELISA method developed in this study because the detection of antibodies had no diagnostic value for PCVD. However, the discrimination ability of the test to detect antibodies in samples with high or low amounts of anti-PCV2 antibodies was very important. Therefore, the double-antibody sandwich ELISA was correlated with a commercial ELISA kit used as reference test. It was observed a decline in the levels of maternally derived antibodies from 7 to 84 days as detected by both tests. Besides, a strong linear correlation was observed between the ELISA tests. In this study, IPMA was not used as reference test because the IPMA (Liu et al. 2004) and IIF (Nawagitgul et al. 2002) might result in a considerable number of false positives due to the low dilution of serum samples in comparison with ELISA. In addition, different epitopes can be recognized by ELISA, IPMA and IIF. The antigens for IIF and IPMA were fixed cells, while the ELISA antigens were soluble. Thus, both types of antigens contain shared and distinct epitopes which will be recognized by different antibodies (Nawagitgul et al. 2002).

\section{CONCLUSIONS}

The standardisation of a traditional method of viral purification and the use of viral antigen prepared from cell cultures were presented in this study as alternative to the viral antigen production.

The use of these methods may be extended to other members of the family Circoviridae and also for the production of polyclonal or monoclonal antibodies.

Currently, this ELISA is being applied in studies of experimental and natural infection, and in monitoring the response to vaccination on commercial farms.

Acknowledgments.- This work was supported by the São Paulo Research Foundation (FAPESP grants 06-57976-6, 06-59002-9); and the National Council for Scientific and Technological Development (CNPq grants 471070/2007-6, 500905/2007-0, 12748/2008-6).

Conflict of interest statement.- The authors have no competing interests. 


\section{REFERENCES}

Allan G.M. \& Ellis J.A. 2000. Porcine circoviruses: a review. J. Vet. Diagn. Invest. 12:3-14.

Allan G.M., Phenix K.V., Todd D. \& McNulty M.S. 1994. Some biological and physico-chemical properties of porcine circovirus. Zentralbl. Veterinarmed. B 41:17-26.

Allan G.M., McNeilly F., Meehan B.M., Kennedy S., Mackie D.P., Ellis J.A., Clark E.G., Espuna E., Saubi N., Riera P., Botner A. \& Charreyre C.E. 1999. Isolation and characterisation of circoviruses from pigs with wasting syndromes in Spain, Denmark and Northern Ireland. Vet. Microbiol. 66:115-123.

Blanchard P., Mahé D., Cariolet R., Truong C., Le Dimna M., Arnauld C., Rose N., Eveno E., Albina E., Madec F. \& Jestin A. 2003. An ORF2 protein-based ELISA for porcine circovirus type 2 antibodies in post-weaning multisystemic wasting syndrome. Vet. Microbiol. 94:183-194.

Castro A.M.M.G., Castro Júnior F.G, Mori C.K., Cruz T.F., Baldin C.M., Budiño F.E.L., Araújo Jr J.P. \& Richtzenhain L.J. 2013. Obtenção de animais negativos para Circovírus suíno 2 oriundos de granjas positivas: estratégia de manejo. Arqs Inst. Biológico, São Paulo, 80:393-399.

Chen H.C.G., Kuo T.Y., Yang Y.C., Wu C.C. \& Lai S.S. 2013. Highly permissive subclone of the porcine kidney cell line for porcine circovirus type 2 production. J. Virol. Methods 187:380-383.

Cheung A.K. 2003. Transcriptional analysis of porcine circovirus type 2 . Virology 305:168-180.

Crowther R.A., Berriman J.A., Curran W.L., Allan G.M. \& Todd D. 2003. Comparison of the structures of three circoviruses, chicken anemia virus, porcine circovirus type 2 and beak and feather disease virus. J. Virol. 77:13036-13041.

Crowther R.J. 1995a. Use of antibodies on solid-phase in capture ELISA, p.161-175. In: Crowther R.J. (Ed.), Methods in molecular biology: ELISA theory and practice. Humana Press, Totowa.

Crowther R.J. 1995b. Theoretical considerations, p.99-114. In: Crowther R.J. (Ed.), Methods in Molecular Biology: ELISA Theory and Practice. Humana Press, Totowa.

Cruz T.F. \& Araujo Jr J.P. 2014. Cultivation of PCV2 in swine testicle cells using the shell vial technique and monitoring of viral replication by qPCR and RT-qPCR. J. Virol Methods 196:82-85.

Ge M., Luo W., Jiang D., Li R., Zhao W., Chen G., Yang X. \& Yu X. 2012. Development and application of a double-antigen sandwich enzyme-linked immunosorbent assay for detection of antibodies to porcine circovirus 2. Clin. Vaccine Immunol. 19:1480-1486.

Gerber P.F., Galinari G.C., Silva M.X., Campos F.S., Reis A.C. \& Lobato Z.I. 2009. Distribution of antibodies against porcine circovirus type-2 (PCV2) in single site and multi-site farrow-to-finish farms in Brazil. Res. Vet. Sci. 87:488-491.

He J., Cao J., Zhou N., Jin Y., Wu J. \& Zhou J. 2013. Identification and functional analysis of the novel ORF4 protein encoded by porcine circovirus type 2. J. Virol. 87:1420-1429.

Huang L., Lu Y., Wei Y., Guo L. \& Liu C. 2011. Development of a blocking ELISA for detection of serum neutralizing antibodies against porcine circovirus type 2. J. Virol. Methods 171:26-33.

Johnstone A. \& Thorpe R. 1996. Production of antibodies, p.34-59. In: Johnstone A. \& Thorpe R. (Eds), Immunochemistry in Practice. Blackwell Science Inc., Massachusetts.

Laemmli U.K. 1970. Cleavage of structural proteins during the assembly of the head of bacteriophage T4. Nature 227:680-685.

Liu C., Ihara T., Nunoya T. \& Ueda S. 2004. Development of an ELISA based on the baculovirus-expressed capsid protein of porcine circovirus type 2 as antigen. J. Vet. Med. Sci. 66:237-242.

Liu J., Chen I., Du Q., Chua H. \& Kwang J. 2006. The ORF3 protein of porcine circovirus type 2 is involved in viral pathogenesis in vivo. J. Virol. 80:5065-5073.
Liu J., Chen I. \& Kwang J. 2005. Characterization of a previously unidentified viral protein in porcine circovirus type 2-infected cells and its role in virus-induced apoptosis. J. Virol. 79:8262-8274.

Marcekova Z., Psikal I., Kosinova E., Benada O., Sebo P. \& Bumba L. 2009. Heterologous expression of full-length capsid protein of porcine circovirus 2 in Escherichia coli and its potential use for detection of antibodies. J. Virol. Methods 162:133-141.

Meerts P., Misinzo G., McNeilly F. \& Nauwynck H.J. 2005. Replication kinetics of different porcine circovirus 2 strains in PK-15 cells, foetal cardiomyocytes and macrophages. Arch. Virol. 150:427-441.

Nawagitgul P., Harms P.A., Morozov I., Thacker B.J., Sorden S.D., Lekcharoensuk C. \& Paul P.S. 2002. Modified indirect porcine circovirus (PCV) type 2-based and recombinant capsid protein (ORF2)-based enzymelinked immunosorbent assays for detection of antibodies to PCV. Clin. Diagn. Lab. Immunol. 9:33-40.

Nawagitgul P., Morozov I., Bolin S.R., Harms P.A., Sorden S.D. \& Paul P.S. 2000. Open reading frame 2 of porcine circovirus type 2 encodes a major capsid protein. J. Gen. Virol. 81:2281-2287.

Pérez-Martín E., Grau-Roma L., Argilaguet J.M., Nofrarías M., Escribano J.M., Gómez-Sebastián S., Segalés J. \& Rodríguez F. 2008. Development of two Trichoplusia ni larvae-derived ELISAs for the detection of antibodies against replicase and capsid proteins of porcine circovirus type 2 in domestic pigs. J. Virol. Methods 154:167-174.

Pogranichnyy R.M., Yoon K.J., Harms P.A., Swenson S.L., Zimmerman J.J. \& Sorden S.D. 2000. Characterization of immune response of young pigs to porcine circovirus type 2 infection. Viral Immunol. 13:143-153.

Rodríguez-Arrioja G.M., Segalés J., Balasch M., Rosell C., Quintant J., Folch J.M., Plana-Durán J., Mankertz A. \& Domingo M. 2000. Serum antibodies to porcine circovirus type 1 and type 2 in pigs with and without PMWS. Vet. Rec. 146:762-764.

Segalés J. 2012. Porcine circovirus type 2 (PCV2) infections: clinical signs, pathology and laboratory diagnosis. Virus Res. 164:10-19.

Shang S.B., Li Y.F., Guo J.Q., Wang Z.T., Chen Q.X., Shen H.G. \& Zhou J.Y. 2008. Development and validation of a recombinant capsid protein-based ELISA for detection of antibody to porcine circovirus type 2. Res. Vet. Sci. 84:150-157.

Smith P.K., Krohn R.I., Hermanson G.T., Mallia A.K., Gartner F.H., Provenzano M.D., Fujimoto E.K., Goeke N.M., Olson B.J. \& Klenk D.C. 1985. Measurement of protein using bicinchoninic acid. Anal. Biochem. 150:76-85.

Sorden S.D., Harms P.A., Nawagitgul P., Cavanaugh D. \& Paul P.S. 1999. Development of a polyclonal-antibody-based immunohistochemical method for the detection of type 2 porcine circovirus in formalin-fixed, paraffin-embedded tissue. J. Vet. Diagn. Invest. 11:528-530.

Spencer K.A., Osorio F.A. \& Hiscox J.A. 2007. Recombinant viral proteins for use in diagnostic ELISAs to detect virus infection. Vaccine 25:56535659.

Sun S.Q., Guo H.C., Sun D.H., Yin S.H., Shang Y.J., Cai X.P. \& Liu X.T. 2010. Development and validation of an ELISA using a protein enconded by ORF2 antigenic domain of porcine circovirus type 2. Virol. J. 7:274.

Tischer I., Rasch R. \& Tochtermann G. 1974. Characterization of papovavirus- and picornarvirus -like particles in permanent pig kidney cell lines. Zentralbl. Bakteriol. Org. A 226:153-167.

Tischer I., Peters D., Rasch R. \& Pociuli S. 1987. Replication of porcine circovirus: induction by glucosamine and cell cycle dependence. Arch. Virol. 96:39-57.

Tischer I., Bode L., Peters D., Pociuli S. \& Germann B. 1995. Distribution of antibodies to porcine circovirus in swine populations of different breeding farms. Arch. Virol. 140:737-743.

Walker I.W., Konoby C.A., Jewhurst V.A., McNair I., McNeilly F., Meehan B.M., Cottrell T.S., Ellis J.A. \& Allan G.M. 2000. Development and application of a competitive enzyme-linked immunosorbent assay for the detection of serum antibodies to porcine circovirus type 2. J. Vet. Diagn. Invest. 12:400-405. 